\title{
The Potential of VLE in Providing Access to Quality Education in Rural Community Schools - Myth or Reality
}

\author{
Najim Ussiph \\ Department of Computer Science \\ Kwame Nkrumah University of \\ Science and Technology, \\ Kumasi. Ghana
}

\begin{abstract}
This study examines the use of virtual learning environment (VLE) to support teaching and learning in rural communities in Ghana by exploring a more efficient and sustainable means of access to information and communication technology for rural communities to enable and empower them to be able to play a more meaningful role in the Information Society. The research environment is a local community college in a rural community in Ghana. Teaching with a learning management system, Moodle and a web-conferencing application, WizIQ were introduced in a pilot project. Initial orientation was given to student participants and two support staff prior to actual commencement of the research project.
\end{abstract}

The research method employed was Participatory Action Case Study method - a new hybrid extension to the Action Case method - developed in the course of this research in adaptation to peculiar characteristics and constraints of the research environment. Research cycles were carefully planned, implementation and observations were made and data collected using participant observations, interviews, and focus group. The impact of the project was assessed within an academic term with respect to (i) students' motivation / interest, (ii) whether or not there has been improvement in academic performances, (iii) ICT awareness and e-literacy and (iv) enriched learning experience.

A multi-system pedagogy was adapted for the introduced technology-mediated learning. It emerged that the level of technology available is unable to support content delivery using web conferencing; however participants were able to take advantage of Moodle courseware aspect to improve performance and enrich learning experience. The technology-mediated delivery of teaching and learning raised learners' motivation, increased e-literacy level and ICT awareness of participants but reveals challenges that need both public and private support if the project is to be sustained and for learners to derive full benefit of the initiative.

\section{Keywords}

Virtual Learning Environment, VLE, ICT, e-literacy, Moodle, WizIQ, Learning Experience

\section{INTRODUCTION}

There is little agreement among researchers and academics on the appropriate term to use for online learning environment, what it actually is and where its boundaries with other systems lie. The term 'virtual' in Virtual Learning Environment (VLE) sounds unreal to some just as it is the meaning of virtual thereby incurring their rejection. The alternative, Learning Management System (LMS) also connotes the suggestion that it 'manages' students learning somehow. That also contradicts the inherent approach of explanatory and constructivism in elearning that fascinate many. (Weller et al, 2005) cited (JISC, 2000) that the term refers to "the components in which learners and tutors participate in on-line interaction of various kinds including on-line learning." On the other hand, Whatis.com defines LMS as a software application or web-based technology used to plan, implement and assess a specific learning process. Typically, an LMS provides an instructor with a way to create, and deliver content, monitor student participation, and assess student performance. A LMS may also provide students with the ability to use interactive features such as threaded discussions, video conferencing and discussion forums.

However, in other not to get drawn into the controversy, and for the sake of simplicity and clarity, we may view VLE as an environment in which e-learning learning can be conducted or simpler, as a superset of ICT tools to facilitate e-learning.

\section{E-LEARNING}

Like many other concepts and innovations in ICT, elearning does not have a rigid definition and many authors and researchers have defined or described it in many ways. E-learning is networked online learning that takes place in formal context and uses a range of multimedia technology (Garrison and Anderson, 2003). It has also been described as many different learning approaches that have in common the use of ICT (Clark and Mayer, 2008). Murray has given it a simplistic description as being computerfacilitated instruction and learning oriented interaction (Murray, 2007). Summarily, e-learning may be described as a modern learning technology that is used to communicate or transfer knowledge, or perform teaching and learning activities interactively from afar with the aid of ICT tools. The use of technology in teaching and learning dated centuries back. What is however unique about e-learning is its multi-modal methodologies. It incorporates different media such as text, audio, and video. It can also be synchronous or asynchronous. E-learning has come to revolutionize the way traditional distance learning was conducted and it is indeed learning 'san frontier'.

(Weller, 2002) identified five reasons why e-learning has gained wide acceptance and likely to continue for a long time to come unlike other learning technologies that has fizzled away with time. These reasons include social 
acceptance, educator proximity, generic interface, interaction and personalization and finally, disruptive and sustaining technology

Besides these reasons advanced by Weller, e-learning has other characteristics that makes it to stand out among all other learning technologies. E-learning is location independent as well as content independent. Knowledge can therefore be tapped from and taken to any corner of the world no matter how remote using appropriate network technology. It can also be time independent particularly in asynchronous form. Cost is an important factor in deploying any form of technology to the rural community. E-learning can attain a wide reach at low cost if implemented and managed properly. It can also be maintained at minimal cost. Teaching process can be automated, thus minimizing the effect of lack of qualified teaching personnel. Informal training can be maximized giving rise to new opportunities for non-professionals to find new roles.
There are several modes or forms of e-learning that can broadly be categorized into two; namely synchronous and asynchronous. Synchronous e-learning is sometime referred to by other names like web conference, webinars, virtual classroom and online presentation among others.

What all these names have in common however, is the use of computer network and software to facilitate live, interactive learning transaction via the internet. In synchronous e-learning, learning takes place in real time, that is, instantly and interactively between the teacher and students. It is usually scheduled and time-specific. In asynchronous e-learning, collaboration, communication or access takes place intermittently. It is self-paced and available at any time. (Murray, 2007) outlines distinctive features and some examples of synchronous and asynchronous e-learning as shown in Table 1 below.

Table1 Synchronous vrs Asynchronous e-learning

\begin{tabular}{|c|c|c|}
\hline & Distinctive features & Examples \\
\hline $\begin{array}{l}\text { Synchronous } \\
\text { e-learning }\end{array}$ & $\begin{array}{ll}\text { - } & \text { Real-time } \\
\text { - } & \text { Live } \\
\text { - } & \text { Usually scheduled and time- } \\
\text { - } & \text { Specific } \\
\text { - } & \text { Collective and collaborative } \\
\text { - } & \text { of teacher and learners } \\
\quad \text { Concurrent }\end{array}$ & $\begin{array}{ll}\text { - } & \text { Instant messaging } \\
\text { - } & \text { Online chart } \\
\text { - } & \text { Live Webcasting } \\
\text { - } & \text { Audio conferencing } \\
\text { - } & \text { Video conferencing } \\
\text { - } & \text { Web conferencing }\end{array}$ \\
\hline $\begin{array}{l}\text { Asynchronou } \\
\text { s e-learning }\end{array}$ & $\begin{array}{ll}\text { - } & \text { Intermittent access or } \\
\text { interaction } \\
\text { - } & \text { Self-paced } \\
\text { - } & \text { Individual or intermittently } \\
\text { collaborative } \\
\text { - } & \text { Independent learning } \\
\text { - } & \text { Usually available any time } \\
\text { - } & \text { Recorded or pre-produced }\end{array}$ & $\begin{array}{ll}\text { - } & \text { Email } \\
\text { - } & \text { Threaded discussion } \\
\text { - } & \text { Boards } \\
\text { - } & \text { Web-based training } \\
\text { - } & \text { Podcasting } \\
\text { - } & \text { VCD or DVD } \\
\text { - } & \text { Computer-based training }\end{array}$ \\
\hline
\end{tabular}

\section{LITERATURE REVIEW}

It has been argued in the literature (Mossburger et al, 2003; Warschauer, 2002; Kvasny, 2005) that having access to computers and the Internet alone is not sufficient to make meaningful impact if individuals do not possess the basic skills and other resources to take advantage of technology. Mossburger et al (2003) articulate that information technology skills are "public goods" and like education and libraries, have the potential to fuel socio-economic development particularly within the context of knowledge economy. However, literacy and education, community and institutional structures must all be taken into account if meaningful access to new technologies is to be provided (Warshauer, 2002). In the argument of Kvasny (2005), endorsing public access and computer training though justified, it is not enough to address other "social forces" that may limit those endeavors. The issue is therefore not only about access but also about use or ability to take advantage of technology - needs that cannot be dissociated from other social and economic factors such as poverty and literacy level. Summarily, it can be seen in the light of the discussion above that just as the information revolution comes with the potential to dramatically raise socioeconomic status of communities and nations it also has the inherent danger of marginalization within and across communities and nations. Contemporary ICT can be used to provide access to better education if only it is carefully planned and appropriately deployed.

It is important, at this point to state that this study does not assume a technology deterministic stance - the belief that technology shapes social practices including learning - as this have been proven to be problematic (Warschauer, 2002; Kvasny, 2005; Connole and Oliver, 2007). The primary focus of this study is not only on access but also on usage within the context of teaching and learning and to assess impact (tentatively) of the intervention. Integrating technology into educational environment requires skills, capabilities and involves adjustments in attitudes and policies (Mossberger et al, 2003). The step from usage to measurable impact goes beyond access and entails the effective integration of technology into communities, institutions, and societies (Hilbert, 2011). This implies cultural transformations and the modernizations of the way tasks are carried out. Changes will be required in the most 
basic protocol of daily routines, as well as changes in setting priorities of long-established procedures.

The conduit model (Warschauer, 2002) is seen to provide a better comparative model for ICT diffusion than do devices but requires connection to a supply line for resources such as electricity and telephone service and involves a high level social mobilization and struggle to insure equal access. It has been argued that "what is most important about ICTs is not so much the availability of the computing device or the Internet line, but rather people's ability to make use of that device and line to engage in meaningful social practices" (Warschauer, 2002; p.9). Warschauer goes further to identifies five similarities between literacy and ICT access which include communication, participation in society or social inclusion, connection to artifact, content and skill level, consumption and production of information and link to notion of societal divide.

Literacy acquisition requires variety of resources and the development of skills, knowledge with the right attitude and motivation to make meaningful use of technology. These characteristics of literacy suggest the basis of a model for ICT access. ICT use is therefore seen as a social practice involving physical access to devices, relevant contents, skills, and social support. ICT access for advancement of social inclusion will have to be rooted in harnessing of range of resources developed and promoted to enhance the socio-economic status of the target communities. All these are matters of not only education but also of power and privilege (Warschauer, 2003; Kvasny, 2005). Warschauer proposes range of resources that will need to be mobilized for ICT access for the social inclusion of disadvantaged communities. These include

1. Physical Resources: access to computers, accessories and the internet

2. Digital Resources: needed application software and relevant online or digital materials

3. Human Resources: trainers or instructors on literacy and education to provide basic skills needed for computer use and online communication

4. Social Resources: societal structures such as community or institution that provides support for ICT infrastructure (see Figure 1)

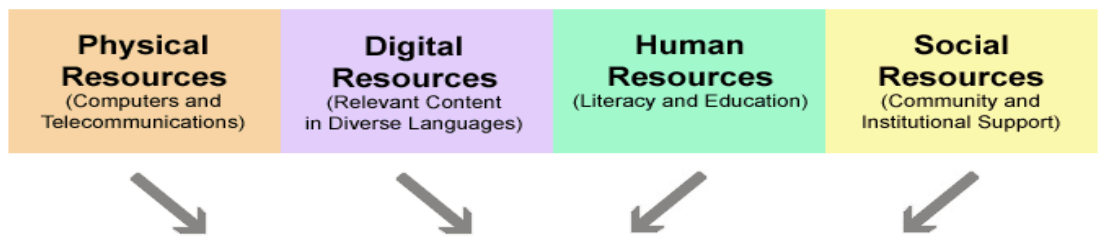

\section{Effective Use of ICTs to Access, Adapt, and Create Knowledge}

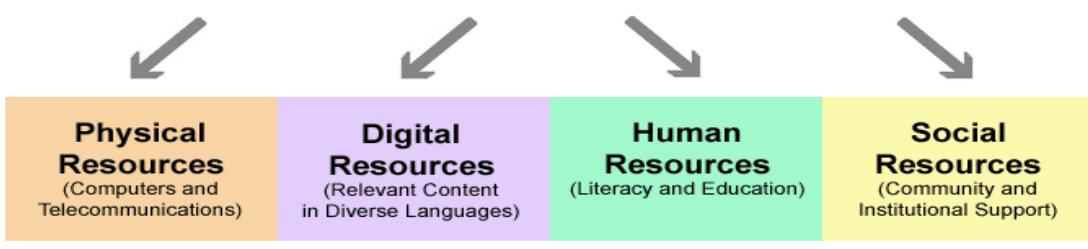

Figure 1 Effective Use of ICTs. (adapted after Warschauer, 2002)

The combination of these set of resources and their proper management can contribute to effective access to and use of information, creation of knowledge and eventually promote social inclusion and development.

Upon exploring and synthesizing the body of literature as expounded above, I put forward a conceptual framework
(Figure 2) within the context of this research: how to support teaching and learning using ICT, provide access to information and promote meaning use of information in rural communities. 


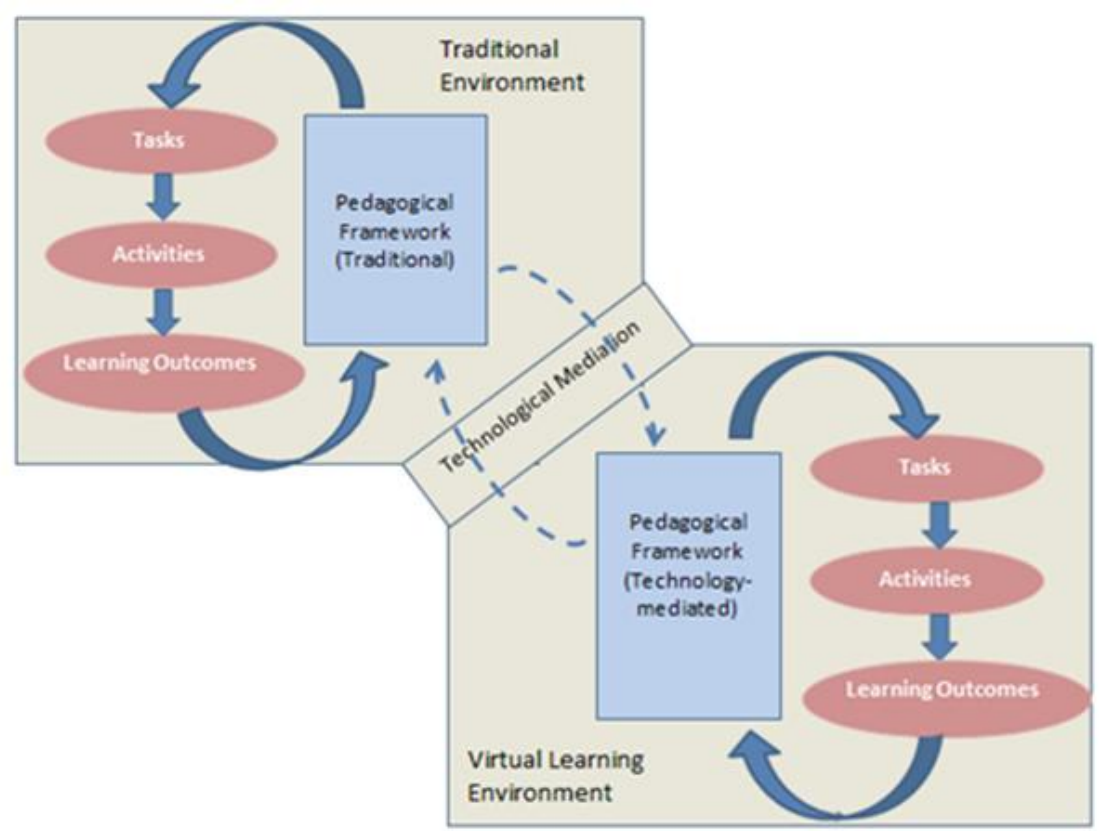

Figure 2. Conceptual Framework

The purpose of the framework is to explain the key factors or elements, constructions or variables in the study and the presumed relationships among them (Miles and Huberman, 1994). This framework is the synthesis of Goodyear et al (2001) model for network learning and the model for internetenabled student collaboration (Whatley and Bell, 2001) adapted to fit the context of this research.

As highlighted in the figure, the key factors under investigation are pedagogies employed in the delivery of teaching and learning in traditional form and in technologymediated environment. Variables in the framework include the various strategies employed in the execution of the pedagogies through tasks and activities that are consistent with the pedagogical strategies being applied to eventually generate learning outcomes. The learning outcomes feed back into the pedagogies for effectiveness check and / or modification as suggested by Kuhn (1962). The outcomes of the learning cycles in the two environments reverberate into each other for theory adjustment if and when necessary.

\section{METHODOLOGY}

In implementation, I used Participatory Action Case Study form of action research that combines with case study to execute the cyclic phases of the research implementation and data collection. Action research method (Figure 3) has been recognized as a form of experimental research that focuses on the effects of the researcher's direct actions of practice within a participatory community with the goal of improving the performance quality of the community or an area of concern (Dick, 2002; Bradbury and Reason, 2001; Hult \& Lennung, 1980; McNiff, 2002). In recent years, Participatory action research has emerged as a significant methodology for intervention, development and change within a system, organization, institution, communities or groups. PAR is not just research which is hoped that will be followed by action. It is action which is researched, changed and re-researched, within the research process by participants (Wadsworth, 1998). This study therefore apply interpretive case study with participatory action research to gain deep and contextualized insight into using virtual learning environment to support teaching and learning and making an intervention to effect a positive change.

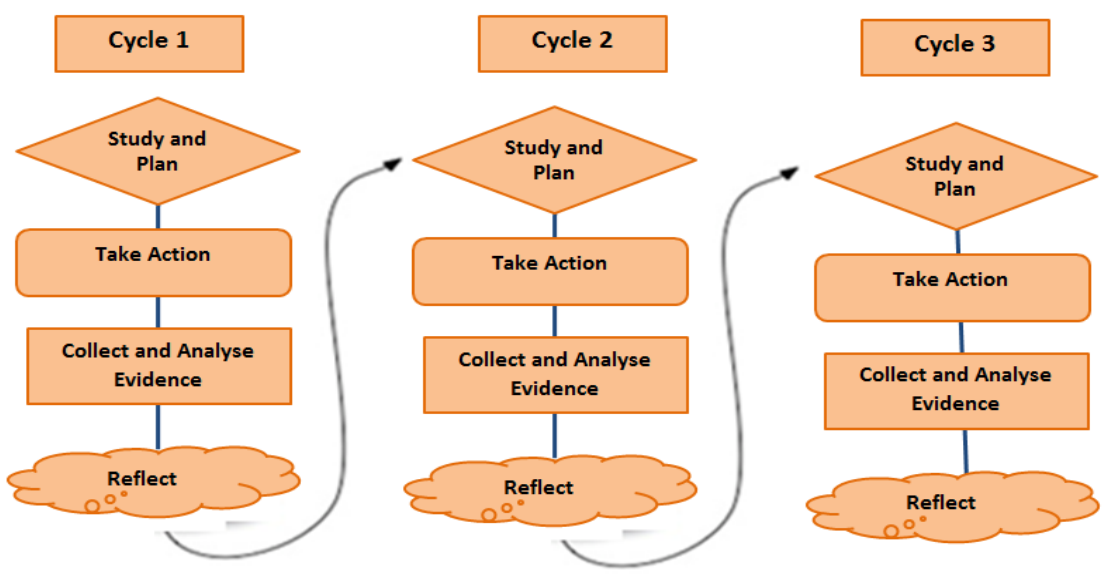

Figure 3 Problem Solving with Action Research (http://cadres.pepperdine.edu/ccar/define.html) 
In this research, the researcher assumes the role of participant/observer throughout various cycles of implementation to collect data. Data analysis was carried alongside data collection as the research progresses in conformity with standard practice in PAR (Wadsworth, 1998, Bazeley,2007).

Table 2 Summary of Cycles implementations and activities

\begin{tabular}{|c|c|c|c|}
\hline & Cycle 1 & Cycle 2 & Cycle 3 \\
\hline Planning & $\begin{array}{l}\text { - Acquisition and installation of } \\
\text { wireless modems for internet } \\
\text { connectivity and webcams } \\
\text { - Installation of Moodle and setting } \\
\text { up of WizIQ accounts on PCs } \\
\text { - Training of Support Staff } \\
\text { - Orientation of participants }\end{array}$ & $\begin{array}{l}\text { A second orientation was } \\
\text { planned } \\
\text { - Meeting time was re-scheduled } \\
\text { for early morning when internet } \\
\text { connection was thought to be } \\
\text { faster } \\
\text { - There was to be a repeat of the } \\
\text { first session }\end{array}$ & $\begin{array}{l}\text { It was decided there would } \\
\text { be no WizIQ session at in } \\
\text { this cycle } \\
\text { - Students are to be given } \\
\text { individual and group } \\
\text { assignments } \\
\text { - Focus group discussion } \\
\text { topics will also be given out } \\
\text { - Discussions on learning } \\
\text { experience were also set for } \\
\text { focus group discussion }\end{array}$ \\
\hline Action & $\begin{array}{l}\text { Delivery of first session via web } \\
\text { conferencing from KNUST to } \\
\text { AKGSSS } \\
\text { - Delivery of second session via } \\
\text { web conferencing from KNUST } \\
\text { to AKGSSS } \\
\text { - Delivery of third session via web } \\
\text { conferencing from KNUST to } \\
\text { AKGSSS }\end{array}$ & $\begin{array}{l}\text { Second or repeat orientation } \\
\text { was given } \\
\text { A repeat of the first session was } \\
\text { delivered early morning } \\
\text { (7.00AM) - Summary of the } \\
\text { materials of the earlier sessions } \\
\text { - New session }-1^{\text {st }} \text { for the } 2^{\text {nd }} \\
\text { cycle }- \text { was delivered - } \\
\text { performance was better } \\
\text { Second session of the } 2^{\text {nd }} \text { cycle } \\
\text { disrupted mid-way as a result of } \\
\text { power outage }\end{array}$ & $\begin{array}{l}\text { - } 1^{\text {st }} \text { and } 2 \text { nd sessions of the } \\
\text { Cycle } 3 \text { was based sole on } \\
\text { Moodle courseware } \\
\text { Group assignment was } \\
\text { given out to be submitted } \\
\text { following week at the next } \\
\text { session } \\
3^{\text {rd }} \text { session was conducted } \\
\text { and student had an } \\
\text { assessment on contents } \\
\text { covered so far } \\
\text { - Focus group session was } \\
\text { arranged and conducted }\end{array}$ \\
\hline $\begin{array}{l}\text { Observation and } \\
\text { Data Collection }\end{array}$ & $\begin{array}{l}\text { - Session somehow chaotic- } \\
\text { despite orientation given, } \\
\text { students/participants still } \\
\text { struggled with operational basics } \\
\text { - Lot of time wasted } \\
\text { - Problems with internet connection } \\
\text { speed - very slow for video } \\
\text { transmission } \\
\text { - Students however, took advantage } \\
\text { of electronic materials on lessons } \\
\text { in Moodle }\end{array}$ & $\begin{array}{l}\text { There was general consensus } \\
\text { that the repeat session was very } \\
\text { useful } \\
\text { - Students were more } \\
\text { comfortable with basics and } \\
\text { follow delivery better } \\
\text { - Internet connection speed } \\
\text { though improved slightly but } \\
\text { still less to be desired or below } \\
\text { standard } \\
\text { - Greater concentration of } \\
\text { students was on Moodle than } \\
\text { web conference delivery }\end{array}$ & $\begin{array}{l}\text { Students now have } \\
\text { confidence using Moodle } \\
\text { and are able to make } \\
\text { progress with minimal } \\
\text { support } \\
\text { - Before the } 3^{\text {rd }} \text { session of the } \\
\text { Cycle } 3 \text { interactions } \\
\text { between students via email } \\
\text { had been more purposeful } \\
\text { - Focus groups discussion } \\
\text { mostly drifted towards } \\
\text { preference of Moodle to } \\
\text { WizIQ delivery. Course } \\
\text { materials were found to be } \\
\text { most helpful }\end{array}$ \\
\hline $\begin{array}{l}\text { Reflection \& } \\
\text { Evaluation }\end{array}$ & $\begin{array}{l}\text { - In later discussion with students } \\
\text { and support staff: } \\
\text { - it was agreed that another session } \\
\text { of orientation be organized } \\
\text { - Find a more suitable time when } \\
\text { internet connection traffic might } \\
\text { be less for improved connection } \\
\text { speed } \\
\text { - Student felt more comfortable } \\
\text { with Moodle courseware } \\
\text { - Students share knowledge and } \\
\text { experience with each via emails }\end{array}$ & $\begin{array}{l}\text { - Confirmation of inconsistent } \\
\text { power supply problem } \\
\text { It was agreed that Moodle } \\
\text { lessons be enriched and used } \\
\text { rather than WizIQ } \\
\text { - There has been sharp increase } \\
\text { in email correspondence among } \\
\text { students. However just about } \\
\text { half or less was on course } \\
\text { discussion. } \\
\text { Assignments and topics for } \\
\text { focus groups be given out to } \\
\text { increase attention of students to } \\
\text { main purpose of research / } \\
\text { project }\end{array}$ & $\begin{array}{l}10 \text { and } 2 \text { support staff were } \\
\text { interviewed } \\
\text { Dominant theme came out } \\
\text { to be need of more technical } \\
\text { assistance-hardware and } \\
\text { software support, financial } \\
\text { assistance towards provision } \\
\text { of accessories - modems, } \\
\text { web cams - is much needed } \\
\text { Need for stable power } \\
\text { supply through provision of } \\
\text { diesel power generator }\end{array}$ \\
\hline
\end{tabular}




\begin{tabular}{|c|c|c|c|}
\hline Emerging Issues & $\begin{array}{l}\text { - It will take a while before } \\
\text { students are able to participate in } \\
\text { session without support staff in } \\
\text { attendance } \\
\text { - For success of web conferencing, } \\
\text { remedy will have to be found for } \\
\text { low connection speed } \\
\text { - Meeting times may have to be } \\
\text { rescheduled } \\
\text { - Extra meetings may have to be } \\
\text { arranged }\end{array}$ & $\begin{array}{l}\text { Web conferencing has been less } \\
\text { successful due to inadequacies } \\
\text { of internet connection } \\
\text { Moodle courses are winning } \\
\text { students heart more than WizIQ } \\
\text { Students feel less enburdened } \\
\text { by having electronic learning } \\
\text { materials to fall on for learning } \\
\text { - Few students - more IT savvy } \\
\text { ones - take extra time to } \\
\text { browse for more learning } \\
\text { materials on topics covered }\end{array}$ & $\begin{array}{l}\text { In spite of technical } \\
\text { problems encountered } \\
\text { motivations were high. } \\
\text { There was an overall } \\
\text { consensus that learning } \\
\text { experience was far greater } \\
\text { with this system or method } \\
\text { of learning than in the } \\
\text { traditional classroom } \\
\text { method }\end{array}$ \\
\hline
\end{tabular}

\section{FINDINGS AND CONCLUSION}

Summary of the research cycles, findings and emerging issues are presented in Table 2 above. From the initial stages of research implementation through final stages, it emerged that students could be motivated by giving a chance to play more contructive role in learning process rather than being passive 'receptacles' of knowledge. By playing active role in the learning process, students become more innovative, create learning objects on their own and circumvent obstacles or challenges that come their way. As indicated in this research, when delivery through WizIQ was hampered by low speed internet connection, students were able to adjust quickly and take alternative path of taking maximum advantage of Moodle course materials and other collaborative tools that the virtual learning environment to maximize learning experience.

It also emerged that, e-learning with all its potential will still need some amount of face -to-face teacher mediation for students to reap the maximum benefit. Lastly, no matter how good an electronic system of delivering teaching and learning is, it cannot totally replace human being and the plight of rural students and learners can only be alleviated by deserved attention and political will of policy makers to make the minimum contribution to provide enabling environment and basic infrastructure like regular power supply.

\section{REFERENCES}

[1] Anderson, T., \& Elloumi, F. (Eds.). (2004). Theory and Practice of Online Learning: Athabasca Univesity.

[2] Baskerville, R. L. (1999). Investigating Information With Action Research. Communications of the Association for Information Systems, Vol. 2(No. 19).

[3] Bazeley, P. (2007) Qualitative Data Analysis Using NVivo, Sage Publication Ltd, London

[4] Bruce, W. D. e. a. (2007). Technology Mediated learning: Building Capacity In Rural Communities The Journal of Community Informatics, 3(4).

[5] Bradbury, H., \& Reason, P. (Eds.). (2001). Conclusion: Broadening the Bandwidth of Validity: Issues and Choice for Improving the Quality of Action Research. London: Sage.

[6] Clark, R. C. \& Mayer, R. E. (2008) e-Learning and the Science of Instruction: Proven Guidelines For Consumers and Designers of Multimedia Learning $2^{\text {nd }}$ Ed. San Francisco: John Wiley \& Sons Inc.

[7] Cole, J., \& Foster, H. (2008). Using Moodle: Teaching With Popular Open Source Course Management System. Sebastopol, CA 95472 USA: O'Reilly Media Inc.
[8] Connole, G., \& Oliver, M. (Eds.). (2007). Contemporary Perspectives In E-Learning Research: Themes, Methods and Impact on Practice. New York, USA: Routledge Tailor \& Frances Group.

[9] Dick, B. (2002). Action Research: Action and Research. Retrieved from <http://www.scu.edu.au/ schools/gcm/ar/arp/aandr.html>

[10] Garrison, D. R., \& Anderson, T. (2003). E-Learning in the 21st Century - A Framework for Research and Practice: RoutledgerFalmer Publishers, USA.

[11] Goodyear, P., Jones, C., Asensio, M., Hodgson, V., \& Steeples, C. (2001). Students' experiences of networked learning in higher education, fi nal project report $(2$ vols) . Bristol: Joint Information Systems Committee (JISC).

[12] Heinze, A., \& Procter, C. (2004, 13th-14th September, 2004). Reflections On The Use Of Blended Learning. Paper presented at the Education In A Changing Environment, University of Salford, Salford.

[13] Hilbert, M. (2011). The End Justifies the Definition: The manifold outlooks on the digital divide and their practical usefulness for policy-making. Telecommunications Policy 35 (2011) p.715-736

[14] Hult, M., \& Lennung, S. (1980). Towards a definition of action research: a note and a bibliography. Journal of Management Studies, 17, 241-250.

[15] Hyder, K. e. a. (2007). The eLearning Handbook On Synchronous e-Learning Available from www.elearningguide.com <http://www.elearningguide.com>

[16] JISC (2003) Effective Use of VLEs Available at http://tools.jiscinfonet.ac.uk/downloads/vle/what-isvle.pdf. Accessed 21/9/2009

[17] Jones, E. R., \& Cooke, L. (2006). A window into learning: case studies of online group communication and collaboration ALT-J Research in Learning Technology, Vol. 14(No. 3), 261-274.

[18] Kvasny, L. (2005). The Role of the Habitus in Shaping Discourses about the Digital Divide. Journal of Computer-Mediated Communication Vol. 10 (2).

[19] McNiff, J \& Whitehead (2009). Doing and Writing Action Research, Sage Publications Ltd., London

[20] Miles, M., \& Huberman, M. (1994). Qualitative Data Analysis: An Expanded Sourcebook. London: Sage Publications. 
[21] Mossburger, K., Tolbert, J.C. \& Stansbury, M. (2003) Virtual Inequality: Beyond The Digital Divide. Washington, D.C.: Georgetown University Press

[22] Murray, M. (2007) The eLearning Guild's Handbook on Synchronous e-Learning. The eLearning Guide, Santa Rosa, CA 95404 USA. Available at http://ww.w.cedmaeurope.org/newsletter/articles/misc/eLearning Guild Handbook on Synchronous e-Learning 28Jan 2007 29.pdf. Accessed 20/8/2009

[23] Ussiph, N. (2010) VLE and Its Impact on Learning Experience of Students: Echoes From Rural Community School In Ghana, E-Learn 2010--World Conference on E-Learning in Corporate, Government, Healthcare, and Higher Education, Orlando, Florida, USA.

[24] Wadsworth, Y. (1998). What is Participatory Action Research? Action Research International, Paper 2. Retrieved from Available on-line: http://www.scu.edu.au/schools/gcm/ar/ari/pywadsworth98.html

[25] Warschauer, M (2002) Reconceptualising the Digital Divide. First Monday, Volume 7, Number 7 - 1 July
2002

[26] Weller, M. (2000). Motivating For Using The Web In Teaching. WebNet Journal, Vol. 2(No. 3).

[27] Weller, M. (2002). Delivering Learning on the Net - The What \& How of Online Education: RoutledgeFalmer Publishers, UK

[28] Weller, M. (2007). Virtual Learning Environments: Using, Choosing and Developing Your VLE: RoutledgeFalmer Publishers, UK

[29] Weller, M., Pegler, C., and Mason, R. (2005) Student Experience of Component Versus Integrated Virtual Learning Environments. Journal of Comuter Assisted Learning 21(4) pp. 253-9(7).

[30] Whatley, J. E., \& Bell, F. (2001). Collaboration on teamwork projects across borders. ALT Conference, September 2001

[31] William, H., \& Rice, I. (2006). Moodle E-Learning Course Development - A Complete Guidance To Successful Learning Using Moodle. Birmingham: Packt Publishing Ltd. 